\title{
PENGEMBANGAN PETERNAKAN SAPI POTONG UNTUK PENINGKATAN PEREKONOMIAN PROVINSI JAWA TENGAH: SUATU PENDEKATAN PERENCANAAN WILAYAH
}

\author{
$\underline{\text { Yuliana Susanti }{ }^{1} \text {, Dominicus Savio Priyarsono }}{ }^{2}$ dan Sri Mulatsih ${ }^{2}$ \\ 1)Direktorat Jenderal Peternakan dan Kesehatan Hewan, Kementerian Pertanian RI \\ 2)Departemen Ilmu Ekonomi, Fakultas Ekonomi dan Manajemen, Institut Pertanian Bogor \\ e-mail : 1)yulianasusanti05@yahoo.co.id
}

\begin{abstract}
Beef cattle development based on regional planning approach is one of efforts to increase the role of beef cattle in Central Java Province, by synergizing between its commodity and the region potency. This study aims to analyze the role of beef cattle in the economy of Central Java and its potential development based on regional planning. The analysis instrument used to answer the aim of this research is descriptive analysis, LQ (Location Quotient), KPPTR (Ruminant Population Increased Capacity) and schallogram analysis. The results showed that the role of beef cattle in Central Java Province make a positive contribution to fulfill the demand for beef, but the beef cattle contribution for GDRP and labor is still relatively small. Central Java has considerable potency for the development of beef cattle since it is even now able to increase the ruminant population amounting 5.232.130 AU (Animal Unit) based on TDN (Total Digestible Nutrient), which scattered in 17 districts of the 21 districts designated as the development regions of beef cattle. The base region of beef cattle in Central Java Province located in 7 (seven) districts, but based on the results of the physical assessment of services capacity of these regions considered remain relatively low and middling. The strategy to increase the role of beef cattle in the economy of Central Java is by classifying the regions into 4 groups: namely based on the source of forage, the region base of beef cattle, and the level of service capacity of beef cattle development.
\end{abstract}

Keywords: beef cattle, economy, regional planning

\section{PENDAHULUAN}

Sapi potong merupakan salah satu ternak ruminansia yang mempunyai kontribusi terbesar sebagai penghasil daging, serta untuk pemenuhan kebutuhan pangan khususnya protein hewani. Berdasarkan Rencana Strategis Ditjen Peternakan dan Kesehatan Hewan Tahun 2010-2014 (Ditjen PKH 2011), daging sapi merupakan 1 dari 5 komoditas bahan pangan yang ditetapkan dalam RPJMN 2010-2014 sebagai komoditas strategis.

Konsumsi daging sapi nasional pada tahun 2005 sebesar $0,99 \mathrm{~kg}$ per kapita per tahun dan terus meningkat sampai tahun 2012 hingga menjadi 2,16 kg per kapita per tahun (BKP 2013). Permintaan daging sapi tersebut diperkirakan akan terus meningkat seiring dengan pertumbuhan ekonomi nasional, meningkatnya kesadaran masyarakat akan pentingnya protein hewani, pertambahan jumlah penduduk, dan meningkatnya daya beli masyarakat (Daryanto 2009).

Berdasarkan Badan Pusat Statistik (BPS) dalam P4UI (2013) penyediaan sapi potong dan daging sapi dalam negeri selama ini $97,7 \%$ berbasis peternakan rakyat. Pertumbuhan produksi daging sapi (supply) di dalam negeri dari tahun 2005-2013 terus meningkat, namun belum mampu mengimbangi laju permintaan (demand) yang semakin meningkat, sehingga untuk memenuhi permintaan tersebut diperlukan impor. Kebutuhan daging sapi secara nasional pada tahun 2013 sebesar 391 ribu ton, untuk penyediaannya dipenuhi dari produksi dalam negeri $(69,67 \%)$ dan impor (30,33\%). Impor daging sapi pada tahun 2013 cenderung naik bila dibandingkan dengan tahun 2012 yang hanya $21,29 \%$ dan berdasarkan angka sementara realisasi impor tahun 2014 (bulan 
Oktober) sudah mencapai 33,82\%(Ditjen PKH 2014).

Berdasarkan hasil kajian MB-IPB (2012) Provinsi Jawa Tengah merupakan salah satu wilayah yang memiliki potensi besar dalam pengembangan ternak sapi potong dan penghasil ternak sapi potong terbesar kedua di Indonesia setelah Jawa Timur. Populasi ternak sapi potong dari tahun 2009 terus meningkat hingga mencapai 2,05 juta ekor pada tahun 2012, namun pada tahun 2013 turun 26,88\% menjadi 1,5 juta ekor (Dinas PKH Jateng 2014). Keberadaan sapi potong di Provinsi Jawa Tengah dianggap penting karena telah berkontribusi sebagai pemasok sapi untuk kebutuhan daging nasional, terutama untuk wilayah DKI Jakarta dan Jawa Barat (MB-IPB 2012). Hal tersebut menjadi sorotan utama dalam pembangunan ekonomi Jawa Tengah karena dalam program pemantapan pangan nasional, Provinsi Jawa Tengah merupakan salah satu provinsi penyangga pangan nasional. Selain itu, berdasarkan hasil Sensus Tani 2013 (Dinas PKH Jateng 2014) peternakan sapi potong melibatkan banyak petani yaitu 887.837 rumah tangga petani peternak, sehingga perkembangannya sangat mendukung perkembangan ekonomi masyarakat di perdesaan. Oleh karena itu, adanya permintaan yang tinggi akan daging sapi dalam pasar nasional dan yang cukup tinggi di Provinsi Jawa Tengah merupakan peluang untuk peternak memenuhi pasokan daging sapi tersebut.

Berkaitan dengan hal tersebut di atas, maka pada tahun 2013 pemerintah Provinsi Jawa Tengah telah melakukan terobosan dengan menyusun konsep pengembangan kawasan komoditas strategis sapi potong, dengan menetapkan 21 kabupaten sebagai wilayah pengembangan. Pengembangan komoditas sapi potong berdasarkan perwilayahan tersebut merupakan salah satu upaya untuk meningkatkan peran sapi potong dalam pengembangan wilayah antara lain melalui peningkatan populasi, produksi dan produktivitas ternak. Upaya tersebut dimaksudkan untuk memacu perkembangan ekonomi dengan tetap mempertahankan daya dukung sumberdaya yang tersedia dan memanfaatkan peluang yang ada. Sehingga dalam pengembangan peternakan sapi potong di Provinsi Jawa Tengah diperlukan suatu pendekatan perencanaan wilayah yang dapat mensinergiskan antara potensi pengembangan komoditas dan wilayah.

Pertanyaan penelitian adalah: Bagaimana peranan sapi potong dalam perekonomian wilayah di Jawa Tengah? Bagaimana potensi pengembangannya berdasarkan perwilayahan? Strategi apakah yang tepat untuk pengembangan peternakan sapi potong berdasarkan perencanaan wilayah? Adapun tujuan penelitian ini adalah: 1) Menganalisis peranan sapi potong dalam perekonomian wilayah di Jawa Tengah. 2) Menganalisis potensi pengembangan peternakan sapi potong di Provinsi Jawa Tengah berdasarkan perwilayahan. 3) Merumuskan strategi pengembangan peternakan sapi potong yang tepat berdasarkan perencanaan wilayah.

\section{METODE}

Penelitian dilakukan di wilayah Provinsi Jawa Tengah, yang dipilih secara sengaja (purposive) dengan 21 kabupaten yang ditetapkan sebagai wilayah pengembangan komoditas sapi potong mengacu pada Permentan Nomor 50 Tahun 2012, yaitu: Kabupaten Boyolali, Klaten, Sragen, Sukoharjo, Wonogiri, Karanganyar, Brebes, Tegal, Jepara, Rembang, Grobogan, Pati, Blora, Semarang, Magelang, Temanggung, Wonosobo Kebumen, Purbalingga, Banjarnegara dan Banyumas. Jenis data yang digunakan dalam penelitian ini adalah data sekunder meliputi: populasi sapi potong, produksi dan konsumsi daging sapi (supply-demand), importasi ternak di Indonesia, PDRB, penyerapan tenaga kerja, luas areal lahan penghasil rumput, produksi dan luas panen limbah (hasil samping) pertanian, fasilitas (sarana penunjang) pelayanan usaha sapi potong. Data sekunder diperoleh dari Direktorat Jenderal Peternakan dan Kesehatan Hewan, Dinas Peternakan dan Kesehatan Hewan Provinsi Jawa Tengah, BPS 
Provinsi Jawa Tengah, Badan Ketahanan Pangan (BKP) serta instansi terkait lainnya.

Peranan sapi potong dalam perekonomian Jawa Tengah dijelaskan menggunakan analisis deskriptif yang dilihat dari peranannya terhadap pemenuhan kebutuhan daging sapi baik di tingkat provinsi maupun ditingkat nasional, serta kontribusi sapi potong terhadap PDRB dan tenaga kerja di Provinsi Jawa Tengah (data tahun 2010-2013).

Identifikasi potensi pengembangan sapi potong berdasarkan wilayah sumber hijauan pakan menggunakan analisis KPPTR (Kapasitas Peningkatan Populasi Ternak Ruminansia) yang merujuk pada Direktorat Budidaya Ternak Riminansia Ditjen Peternakan (2006) dalam Lamsihar (2012). Daya dukung hijauan pakan dihitung dengan asumsi bahwa 1 Satuan Ternak (ST) ruminansia rata-rata membutuhkan hijauan pakan berdasarkan TDN (Total Digestible Nutrient) sebesar 1,2045 Ton/Thn, sehingga daya dukung hijauan pakan dihitung berdasarkan penjumlahan antara produksi TDN rumput dengan limbah pertanian (ton/thn) dibagi dengan kebutuhan TDN 1 ST per tahun. Perhitungan nilai KPPTR adalah daya dukung hijauan pakan (ST) dikurangi populasi riil ternak ruminansia (ST), dengan menggunakan data tahun 2013.

Analisis Location Quotient (LQ) untuk mengidentifikasi potensi pengembangan sapi potong berdasarkan wilayah basis menggunakan data PDRB tahun 2013, yang merujuk pada Rustiadi dan Panuju (2012) dengan persamaan sebagai berikut:

dimana :

$$
\mathrm{LQ}_{\mathrm{ij}}=\frac{\mathrm{X}_{\mathrm{ij}} / \mathrm{X}_{\mathrm{i} .}}{\mathrm{X}_{\mathrm{j} j} / \mathrm{X}_{.}}
$$

Tabel 1. Nilai Selang Hierarki (H) Indeks Kapasitas Pelayanan (IKP)

\begin{tabular}{|c|c|c|}
\hline Hierarki & Nilai Selang $(\mathbf{H})$ & $\begin{array}{c}\text { Kategori Kapasitas } \\
\text { Pelayanan }\end{array}$ \\
\hline I & IKP H $>$ [rataan IKP + St Dev IKP] & Tinggi \\
\hline II & Rataan IKP $\leq$ IKP H $\leq$ [rataan IKP + St Dev IKP] & Sedang \\
\hline III & IKP H $<$ rataan IKP & Rendah \\
\hline
\end{tabular}

Sumber: Rustiadi dan Panuju(2012), diolah.
$\mathrm{LQ}_{\mathrm{ij}}=$ Indeks pemusatan usaha sapi potong di wilayah ke-i

Xij = PDRB sapipotong untuk kabuaten ke i (juta rupiah)

Xi. $=$ PDRB total kabupaten ke i (juta rupiah)

X.j = PDRB sapi potong Jawa Tengah (juta rupiah)

X.. = PDRB total Jawa Tengah (juta rupiah)

Identifikasi potensi pengembangan sapi potong berdasarkan tingkat kapasitas pusatpusat pelayanan untuk mendukung pengembangan sapi potong menggunakan analisis skalogram yang merujuk pada Rustiadi dan Panuju (2012). Pendekatan Indeks Kapasitas Pelayanan (IKP) pada analisis skalogram dihitung berdasarkan jumlah dan jenis ketersediaan unit pelayanan pendukung pengembangan sapi potong dari hulu hingga hilir beserta aksesibilitasnya (coverage area), yang selanjutnya dikorelasikan dengan jumlah populasi sapi potong dalam satuan ternak (data tahun 2013). Penyusunan hierarki suatu wilayah menggunakan skalogram berbobot dengan kelas hierarki didasarkan pada nilai standar deviasi (St Dev) IKP dan nilai rataannya, dengan pengelompokan nilai selang hierarki IKP seperti pada Tabel 1.

\section{PERANAN SAPI POTONG DALAM PEREKONOMIAN DI PROVINSI JAWA TENGAH}

Peranan sapi potong dalam perekonomian di Provinsi Jawa Tengah dalam penelitian ini dilihat dari peranannya terhadap pemenuhan kebutuhan daging sapi baik di tingkat provinsi maupun ditingkat nasional, serta sumbangan PDRB dan tenaga kerja. Produksi daging sapi di Provinsi Jawa Tengah pada periode 2010-2013 terus mengalami peningkatan (Tabel 2). 
Tabel 2. Produksi dan Kontribusi Sapi Potong terhadap Perekonomian Jawa Tengah Tahun 2010 - 2013

\begin{tabular}{|c|c|c|c|c|}
\hline \multirow{2}{*}{ Uraian } & \multicolumn{4}{|c|}{ Tahun } \\
\hline & 2010 & 2011 & 2012 & 2013 \\
\hline Produksi daging sapi (ton)a & 51.001 & 60.332 & 60.893 & 61.141 \\
\hline PDRB Jawa Tengah (Rp.) $)^{b}$ & 444.666 .007 & 498.763 .824 & $556.483 .731^{*}$ & $623.749 .617^{* *}$ \\
\hline - sapi potong (juta Rp.) c & 749.523 & 791.753 & $834.699^{*}$ & $880.851^{* *}$ \\
\hline - sapi potong (juta Rp.) b & 1.572 .484 & 1.742 .614 & $1.930 .689^{*}$ & $2.140 .489^{* *}$ \\
\hline - sub sektor peternakan (juta Rp.) b & 12.887 .604 & 14.190 .532 & $15.461 .345^{*}$ & $17.104 .610^{* *}$ \\
\hline - sektor pertanian (juta Rp.) b & 86.665 .685 & 95.078 .349 & $104.311 .416^{*}$ & $114.142 .800^{* *}$ \\
\hline $\begin{array}{l}\text { Sumbangan sapi potong terhadap PDRB } \\
\text { sub sektor peternakan }(\%)\end{array}$ & 12,202 & 12,280 & 12,487 & 12,514 \\
\hline $\begin{array}{l}\text { Sumbangan sapi potong terhadap PDRB } \\
\text { sektor pertanian }(\%)\end{array}$ & 1,814 & 1,833 & 1,851 & 1,875 \\
\hline $\begin{array}{l}\text { Sumbangan sapi potong terhadap PDRB } \\
\text { Jawa Tengah }(\%)\end{array}$ & 0,354 & 0,349 & 0,347 & 0,343 \\
\hline $\begin{array}{l}\text { Tenaga kerja pd komoditas sapi potong } \\
\text { (orang) a }\end{array}$ & 388.614 & 484.388 & 512.852 & 375.019 \\
\hline $\begin{array}{l}\text { - Sumbangan terhadap sub sektor } \\
\text { peternakan }(\%)\end{array}$ & 33,03 & 37,19 & 37,14 & 30,97 \\
\hline - Sumbangan thd sektor pertanian (\%) & 6,92 & 9,01 & 10,13 & 18,34 \\
\hline $\begin{array}{l}\text { - Sumbangan thd tenaga kerja Jawa } \\
\text { Tengah }(\%)\end{array}$ & 2,46 & 3,04 & 3,18 & 2,35 \\
\hline
\end{tabular}

Sumber: a) Dinas PHK Jateng, 2014 (diolah); bc) BPS Provinsi Jawa Tengah' 2010-2013 (diolah)

Keterangan: b) PDRB atas dasar harga berlaku; c) PDRB atas dasar harga konstan tahun 2000; *) angka sementara; **) angka sangat sementara

Kebutuhan daging sapi tahun 2013 di Provinsi Jawa Tengah berdasarkan pemotongan dan pengeluaran ke luar provinsi adalah sebesar 490.202 ekor atau setara dengan 95.942 ton ( 1 ekor sapi $=195,72 \mathrm{~kg}$ daging berdasarkan survei karkas 2012), sedangkan ketersediaan daging berdasarkan potensial stock sebanyak 575.266 ekor (112.591 ton), sehingga terdapat surplus penyediaan sapi potong sebanyak 85.064 ekor atau 16.648 ton daging sapi. Produksi daging sapi di Provinsi Jawa Tengah untuk beberapa periode mengalami surplus, sehingga Jawa Tengah telah mampu menjadi pemasok untuk kebutuhan daging sapi bagi wilayah lain, terutama wilayah DKI Jakarta dan Jawa Barat (MB-IPB 2012). Kontribusi produksi daging sapi Provinsi Jawa Tengah terhadap nasional pada tahun 2013 sebesar 11,21\% (Ditjen PKH 2013), sehingga untuk jangka panjang kedepan peranan wilayah ini sebagai pemasok ternak sapi potong untuk kebutuhan wilayah lain perlu tetap dipertahankan dan ditingkatkan.

Peranan PDRB sapi potong terhadap perekonomian Jawa Tengah dapat dilihat dari kontribusi sapi potong (Tabel 2). Sumbangan sapi potong terhadap sub sektor peternakan dan sektor pertanian dari tahun 2010-2013 atas dasar harga berlaku terus meningkat. Perkembangan PDRB Sapi Potong Provinsi Jawa Tengah atas dasar harga konstan tahun 2000 selama kurun waktu 2010-2013 terus mengalami peningkatan. Kenaikan angka PDRB ini disebabkan adanya kenaikan produksi daging sapi tahun 2010-2013 yang diduga karena adanya beberapa program baik dari pemerintah pusat maupun pemerintah daerah untuk tercapainya Program Swasembada Daging Sapi Tahun 2014. Program pemerintah tersebut diantaranya: program untuk penguatan kelembagaan pada kelompok-kelompok petani peternak seperti Sarjana Membangun Desa (SMD), Lembaga Mandiri yang Mengakar di Masyarakat (LM3); program subsidi kredit seperti KUPS (Kredit Usaha Pembibitan Sapi) dan KPPE (Kredit Ketahanan Pangan dan Energi); serta adanya impor sapi bibit dan lain-lain.

Sumbangan sapi potong terhadap PDRB Provinsi Jawa Tengah dari tahun 2010-2013 terus menurun (Tabel 2). Peranan sapi potong 
dalam perekonomian Jawa Tengah masih relatif rendah jika dilihat dari sumbangannya, hal ini dikarenakan kontribusi nilai tambah bruto sapi potong terhadap PDRB Jawa Tengah masih relatif kecil. Apabila dilihat dari kontribusi masing-masing sektor pada PDRB Provinsi Jawa Tengah, pada tahun 2010-2011 (angka tetap) dan tahun 2012-2013 (angka sementara) atas dasar harga berlaku, maka sektor dengan kontribusi terbesar adalah sektor industri pengolahan (berkisar 32,6\%$33,25 \%)$. Selama empat tahun, sektor ini mengalami peningkatan positif, begitu pula sektor lainnya yang hampir selalu mengalami peningkatan kontribusi positif terhadap PDRB Jawa Tengah, kecuali sektor pertanian yang menunjukkan penurunan kontribusi dari tahun 2010-2013. Pada tahun 2010 sektor pertanian menyumbang $19,49 \%$, dan mengalami penurunan menjadi $18,34 \%$ pada tahun 2013. Selain itu, yang menjadi tantangan perekonomian di Jawa Tengah adalah laju pertumbuhan sektor pertanian termasuk di dalamnya sub sektor peternakan, pertumbuhannya lebih kecil $(2,2 \%)$ bila dibandingkan dengan pertumbuhan rata-rata $(5,8 \%)$, sementara sektor pertanian merupakan andalan untuk tetap mendukung swasembada pangan dan penyerapan tenaga kerja.

Berdasarkan struktur tenaga kerja(BPS Jateng 2013) sektor pertanian masih memberikan kontribusi yang besar pada tahun 2013 yaitu 30\% tenaga kerja di Jawa Tengah masih disumbang dari sektor pertanian. Tabel 2 menunjukkan bahwa struktur tenaga kerja pada komoditas sapi potong tahun 2013 menyumbang $18,34 \%$ untuk sektor pertanian dan 30,97\% untuk sub sektor peternakan. Penyerapan tenaga kerja pada komoditas sapi potong di Provinsi Jawa Tengah pada tahun 2013 hanya mampu menyumbang 2,35\% dari total tenaga kerja. Jumlah tenaga kerja pada komoditas sapi potong pada tahun 2013 turun 26,87\% dari tahun 2012 menjadi 375.019 orang. Penurunan jumlah tenaga kerja di Provinsi Jawa Tengah tersebut terjadi karena adanya pergeseran tenaga kerja dari sub sektor peternakan (peternakan sapi potong) ke sektor non pertanian yaitu sektor industri dan jasa atau tenaga kerja informal.

\section{POTENSI PROVINSI JAWA TENGAH DALAM PENGEMBANGAN SAPI POTONG BERDASARKAN PERWILAYAHAN}

\section{Potensi Pengembangan Sapi Potong Berdasarkan Sumber Hijauan Pakan}

Nilai KPPTR Provinsi Jawa Tengah berdasarkan TDN sebesar 5.232.130 ST (Satuan Ternak). Hal ini menunjukkan bahwa wilayah Jawa Tengah masih dapat menambah populasi ternak ruminansia sebesar nilai KPPTR tersebut. Tabel 3 menunjukkan secara lebih rinci bahwa dari 21 kabupaten yang merupakan wilayah pengembangan sapi potong di Provinsi Jawa Tengah terdapat 17 kabupaten yang memiliki kelebihan ketersediaan hijauan pakan (nilai KPPTR positif) dan 4 kabupaten lainnya mengalami kekurangan ketersediaan hijauan pakan (nilai KPPTR negatif). Kekurangan daya dukung hijauan pakan pada wilayah KPPTR negatif berarti bahwa pada wilayah tersebut memiliki jumlah ternak ruminansia yang lebih banyak dibandingkan dengan potensi sumberdaya hijauan pakan yang berasal dari rumput dan hasil samping/ limbah pertanian (jerami padi, jerami jagung, jerami kacang tanah, jerami ketela rambat, jerami ketela pohon dan daun pucuk tebu).

Potensi pengembangan sapi potong di Provinsi Jawa Tengah cukup besar jika dilihat dari nilai KPPTR. Namun peternakan sapi potong di Jawa Tengah pada umumnya terintegrasi dengan tanaman pangan, sehingga iklim menjadi faktor pembatas dalam penyediaan hijauan pakan (MB-IPB 2012). Berdasarkan hasil penelitian Tabrany (2006) ketersediaan hijauan pakan di Jawa Tengah masih sangat fluktuatif sepanjang tahun. Pada musim hujan akan kelebihan hijauan pakan, sedangkan pada musim kemarau akan kekurangan hijauan pakan. Potensi limbah pertanian di Provinsi Jawa Tengah belum dimanfaatkan secara optimal sebagai pakan ternak, padahal potensinya cukup besar mengingat provinsi ini sebagai salah satu penyangga pangan nasional. 
Tabel 3. Nilai KPPTR Wilayah Pengembangan Sapi Potong di Provinsi Jawa Tengah Tahun 2013

\begin{tabular}{|c|c|}
\hline Kategori & Nilai KPPTR Berdasarkan TDN per Kabupaten \\
\hline $\begin{array}{l}\text { Positif } \\
(+)\end{array}$ & $\begin{array}{l}\text { Blora (1.113.981 ST), Boyolali (833.330 ST), Brebes (533.496 ST), Purbalingga } \\
\text { (558.171 ST), Grobogan (220.986 ST), Jepara (142.251 ST), Pati (98.516 ST), Sragen } \\
\text { (98.858 ST), Banyumas (52.241 ST), Tegal (59.348 ST), Wonosobo (65.265 ST), } \\
\text { Rembang (47.206 ST), Sukoharjo (44.290 ST), Magelang (31.727 ST), Banjarnegara } \\
\text { (20.124 ST), Karangayar (15.908 ST) dan Kebumen (8.173 ST) }\end{array}$ \\
\hline$\underset{(-)}{\text { Negatif }}$ & $\begin{array}{l}\text { Temanggung (-6.313 ST), Klaten (-17.489 ST), Semarang (-36.300 ST) dan Wonogiri } \\
\text { (-79.601 ST) }\end{array}$ \\
\hline
\end{tabular}

\section{Potensi Pengembangan Sapi Potong Berdasarkan Wilayah Basis}

Nilai LQ pada Tabel 4 menunjukkan bahwa dari 21 kabupaten yang merupakan wilayah pengembangan sapi potong di Provinsi Jawa Tengah terdapat 7 kabupaten $(37,02 \%)$ yang merupakan wilayah basis dan 14 kabupaten $(62,98 \%)$ tidak menunjukkan sebagai wilayah basis. Wilayah basis sapi potong secara relatif mempunyai potensi yang lebih besar untuk berperan terhadap peningkatan pertumbuhan ekonomi wilayah kabupaten (PDRB) dibandingkan dengan ekonomi wilayah Provinsi Jawa Tengah. Hal ini berarti bahwa pemusatan usaha sapi potong sebagai mata pencaharian utama masyarakat terjadi pada wilayah basis tersebut, selain itu peternak sebagai pelaku usaha (sumberdaya manusia) memiliki budaya (culture) yang kuat dalam pengembangan usaha sapi potong. Wilayah non basis yang berarti pada wilayah tersebut sapi potong secara relatif mempunyai potensi yang lebih kecil untuk berperan terhadap peningkatan pertumbuhan ekonomi wilayah kabupaten dibandingkan dengan ekonomi wilayah Provinsi Jawa Tengah.

Tabel 4 menunjukkan bahwa jumlah wilayah non basis sapi potong lebih banyak bila dibandingkan dengan jumlah wilayah basis di Provinsi Jawa Tengah. Hal ini disebabkan pengembangan ternak sapi potong di Provinsi Jawa Tengah selama ini masih belum optimal dalam hal produktivitasnya. Berdasarkan hasil kajian dari MB-IPB (2012), rendahnya produktivitas sapi potong di Jawa Tengah antara lain disebabkan peternakan sapi potong pada umumnya terintegrasi dengan tanaman pangan, sehingga iklim menjadi faktor pembatas dalam penyediaan pakan ternak. Para peternak belum memberlakukan sapi potong sebagai usaha agribisnis yaitu ternak sebagai tabungan dan dijual sesuai kebutuhan, kepemilikan ternak umumnya 2-3 ekor, manajemen sederhana, pemanfaatan teknologi seadanya dan harga jual masih mengikuti harga taksiran. Selain itu, pembangunan peternakan selama ini tidak terfokus pada lokasi yang mempunyai potensi dan tidak terintegrasi dalam pengembangannya (Ditjen PKH 2012). Lokasi pembangunan peternakan terpencar di seluruh wilayah sehingga porsi dan skala usahanya kecil-kecil dan sulit untuk mendapatkan dukungan berbagai komponen baik itu infrakstruktur, sumberdaya manusia, kelembagaan maupun komponen teknis lain yang menunjang kegiatan baik hulu maupun hilir.

Tabel 4. Nilai LQ Wilayah Pengembangan Sapi Potong di Provinsi Jawa Tengah Tahun 2013

\begin{tabular}{|c|l|}
\hline \multicolumn{1}{|c|}{ Kategori } & \multicolumn{1}{c}{ Nilai LQ per Kabupaten } \\
\hline \multirow{3}{*}{ Basis } & $\begin{array}{l}\text { Blora }(2,35), \text { Pati }(2,19), \text { Kebumen }(2,14), \text { Rembang }(2,08), \text { Boyolali }(1,92), \\
\text { Grobogan }(1,92), \text { dan Sragen }(1,57)\end{array}$ \\
& $\begin{array}{l}\text { Banyumas }(0,88), \text { Purbalingga }(0,87), \text { Karangayar }(0,84), \text { Wonosobo }(0,79), \text { Klaten } \\
(0,79), \text { Jepara }(0,76), \text { Sukoharjo }(0,64), \text { Temanggung }(0,60), \text { Banjarnegara }(0,49),\end{array}$ \\
& $\begin{array}{l}\text { Wonogiri }(0,46), \text { Semarang }(0,43), \text { Brebes }(0,40), \text { Tegal }(0,24) \text { dan Magelang } \\
(0,13)\end{array}$
\end{tabular}


Tabel 5. Hierarki Wilayah Pengembangan Sapi Potong di Provinsi Jawa Tengah

\begin{tabular}{|c|c|}
\hline Kategori & Nilai LQ per Kabupaten \\
\hline Hierarki 1 & Sukoharjo, Brebes, Tegal dan Banyumas \\
\hline Hierarki 2 & Wonogiri, Grobogan, Temanggung, Wonosobo dan Purbalingga \\
\hline Hierarki 3 & $\begin{array}{l}\text { Boyolali, Klaten, Sragen, Karanganyar, Jepara, Rembang, Pati, Blora, Semarang, } \\
\text { Magelang, Kebumen dan Banjarnegara }\end{array}$ \\
\hline
\end{tabular}

\section{Potensi Pengembangan Sapi Potong Berdasarkan Hierarki Wilayah}

Hasil dari analisis skalogram berdasarkan Indeks Kapasitas Pelayanan (IKP) wilayah menunjukkan adanya hierarki wilayah pengembangan sapi potong di Provinsi Jawa Tengah yang dibedakan menjadi 3 kategori yaitu tinggi, sedang dan rendah (Tabel 5). Jenis unit pelayanan sebagai pendukung pengembangan sapi potong diantaranya yaitu: 1) Sub sistem hulu: industri pakan, industri bibit/bakalan ternak, pos IB (Inseminasi Buatan), industri obat dan vaksin; 2) Sub sistem on farm (budidaya): poskeswan, laboratorium keswan dan kesmavet; 3) Sub sistem hilir: rumah potong hewan, industri pengolah daging dan produk ternak lainnya serta pasar hewan.

Hasil analisis skalogram menunjukkan bahwa banyaknya jumlah sarana pelayanan dan jumlah jenis sarana pelayanan pengembangan sapi potong berhubungan kuat dengan jumlah populasi sapi potong di suatu wilayah. Kabupaten Sukoharjo, Brebes, Tegal dan Banyumas berada pada kategori hierarki 1 yang berarti bahwa banyaknya jumlah sarana pelayanan dan jumlah jenis sarana pelayanan untuk pengembangan sapi potong pada wilayah tersebut sudah mampu memenuhi jumlah operasional yang optimal yang dibutuhkan dari hulu hingga hilir untuk melayani jumlah populasi sapi potong di wilayah tersebut.

Namun demikian, yang menjadi perhatian penting pada tingkat kapasitas pelayanan pengembangan sapi potong di Provinsi Jawa Tengah adalah wilayah basis sapi potong (Kabupaten Blora, Pati, Kebumen, Rembang, Boyolali, dan Sragen) masih tergolong pada kategori hierarki 3 (tingkat kapasitas pelayanan rendah), kecuali Kabupaten Grobogan pada kategori hierarki 2 (tingkat kapasitas pelayanan sedang). Hal ini menggambarkan bahwa jumlah sarana pelayanan dan jumlah jenis sarana pelayanan pada wilayah basis dimaksud belum mampu memenuhi jumlah operasional secara optimal bila dibandingkan dengan jumlah populasi sapi potong di wilayah tersebut.

\section{STRATEGI PENGEMBANGAN SAPI POTONG BERDASARKAN PERENCANAAN WILAYAH}

Permasalahan yang terjadi dalam pengembangan peternakan sapi potong di Provinsi Jawa Tengah berdasarkan hasil penelitian ini adalah: 1) Masih rendahnya kontribusi sapi potong terhadap PDRB dan tenaga kerja di Jawa Tengah; 2) Empat (4) kabupaten yang ditunjuk sebagai wilayah pengembangan sapi potong memiliki KPPTR negatif, dan adanya kendala ketersediaan hijauan pakan pada musim kemarau di Jawa Tengah; 3) Empat belas (14) kabupaten yang ditunjuk sebagai wilayah pengembangan sapi potong merupakan wilayah non basis; 4) Masih rendahnya kapasitas pelayanan untuk mendukung pengembangan sapi potong di wilayah Jawa Tengah, terutama pada wilayah basis. Berkaitan dengan hal itu, maka strategi untuk mengatasi permasalahan pengembangan peternakan sapi potong tersebut adalah dengan pendekatan perencanaan wilayah, yang mensinergiskan antara potensi komoditas sapi potong dengan wilayah.

Pendekatan perencanaan wilayah pada penelitian ini (Tabel 6) dilakukan dengan mengelompokkan wilayah yang berpotensi untuk pengembangan sapi potong berdasarkan hal-hal sebagai berikut:

1. Sumber hijauan pakan. Pengembangan sapi potong memerlukan pengelompokan wilayah yang disesuaikan dengan daya dukung hijauan pakan (Arelovich et al. 
2011; Huyen et al. 2012; Mayulu et. al. 2010; Priyanto 2011).

2. Wilayah basis. Menurut Rustiadi et al. (2011) wilayah basis merupakan faktor penentu dalam pembangunan ekonomi, dimana adanya sistem perwilayahan komoditas diharapkan dapat meningkatkan efisiensi sistem produksi dan distribusi komoditas, karena merupakan suatu upaya memaksimalkan keunggulan komparatif setiap wilayah.

3. Hierarki wilayah berdasarkan tingkat kapasitas pelayanan pendukung pengembangan sapi potong. Ketersediaan fasilitas pelayanan sangat menentukan perkembangan ternak sapi potong karena mempunyai kaitan dengan sebaran populasi, upaya pemerataan dan efisiensi dalam jangkauan (Arfa'I dan Erison 2010).

Berdasarkan ketersediaan hijauan pakan (nilai KPPTR), wilayah basis (nilai LQ) dan hierarki wilayah (tingkat kapasitas pelayanan) pengembangan sapi potong tersebut, kemudian ditentukan strategi pengembangan, serta pemetaan untuk menentukan program produksi sapi potong. Menurut Parakkasi (1999) dalam Safitri (2011) program produksi sapi potong meliputi pembibitan untuk produksi anak (cow calf), pembesaran anak sapi sapihan (growing stocker), dan penggemukan (finisher). Program tersebut masing-masing memiliki kekhususan dalam pengelolaannya. Pemetaan wilayah pengembangan peternakan sapi potong dengan pola pembibitan, pembesaran maupun penggemukan sangat diperlukan untuk mendukung peningkatan populasi ternak. Usaha pembibitan disesuaikan dengan daya dukung ketersediaan hijauan pakan (Mayulu et al. 2010).

Tabel 6 menunjukkan bahwa pada wilayah kelompok 1 (Kabupaten Blora, Boyolali, Kebumen, Rembang, Pati, Sragen dan Grobogan) mempunyai KPPTR positif (kelebihan ketersediaan hijauan pakan). Namun ketersediaan hijauan pakan pada wilayah tersebut masih sangat fluktuatif sepanjang tahun. Pada musim hujan terjadi kelebihan hijauan pakan, sedangkan pada musim kemarau terjadi kekurangan hijauan pakan. Berkaitan dengan hal itu, perlu adanya program pengembangan lumbung hijauan pakan yang melibatkan kelompok-kelompok peternak pada wilayah tersebut, sehingga potensi limbah pertanian yang belum dimanfaatkan secara optimal sebagai pakan ternak dapat diolah menjadi hay dan silase. Pengembangan lumbung hijauan pakan ini tentunya sangat memerlukan penguatan aspek penunjang dari segi teknologi dan kelembagaan. Hasil olahan dari hijauan pakan tersebut dapat disimpan di lumbung pakan dan dapat dipergunakan pada saat kekurangan hijauan pakan pada musim kemarau. Ketersediaan hijauan pakan yang berlebih pada kelompok peternak tersebut dapat di ekspor ke kelompok lain atau pada wilayah lain yang kekurangan ketersediaan hijauan pakan, sehingga peternak dapat memperoleh nilai tambah dari pengolahan hijauan pakan tersebut.

Pemusatan usaha sapi potong sebagai mata pencaharian utama masyarakat terjadi pada wilayah kelompok 1 yang merupakan wilayah basis (LQ > 1). Wilayah kelompok ini telah mampu memenuhi kebutuhan ternak sapi potong untuk wilayahnya sendiri dan mengekspor ke wilayah lain. Peternak sebagai pelaku usaha (sumberdaya manusia) pada wilayah ini memiliki budaya (culture) yang kuat dalam pengembangan usaha sapi potong. Wilayah kelompok ini memiliki tingkat kapasitas pelayanan sedang (hierarki 2) dan rendah (hierarki 3) untuk pengembangan sapi potong dari hulu-hilir. Jumlah sarana pada pusat-pusat pelayanan untuk kegiatan hilir masih belum memenuhi jumlah yang dibutuhkan untuk operasionalnya, sehingga program produksi sapi potong pada wilayah kelompok ini dapat diarahkan pada pada kegiatan hulu yaitu program pembibitan untuk produksi anak (cow calf) atau dapat juga sekaligus dengan programpembesaran anak sapi sapihan (growing stocker).

Wilayah kelompok 1 kedepannya diharapkan dapat menjadi wilayah penyedia sarana pengamanan input untuk kebutuhan 
bibit dan sapi bakalan yang akan digemukkan. Ketersediaan bibit sapi potong merupakan salah satu faktor produksi yang menentukan dalam pemenuhan kebutuhan daging sapi, sehingga diperlukan pengembangan pembibitan secara berkelanjutan (Salim 2013). Berdasarkan informasi dari Dinas Peternakan dan Kesehatan Hewan Provinsi Jawa Tengah, beberapa wilayah yang sudah mengusulkan untuk pengembangan pembibitan sapi potong saat ini adalah Kabupaten Kebumen, Blora, dan Rembang, dengan mengembangkan bibit sapi lokal (PO), terutama pejantan unggul hasil seleksi dan konservasi. Fasilitasi unit pelayanan untuk pengembangan sapi potong pada wilayah ini juga sangat diperlukan terutama pada sarana pemasaran untuk memasarkan bibit ternak dan sapi bakalan seperti pasar ternak yang jumlahnya masih minim.

Wilayah kelompok 2 (Kabupaten Banyumas, Brebes, Sukoharjo dan Tegal) mempunyai KPPTR positif (kelebihan ketersediaan hijauan pakan) sama seperti wilayah kelompok 1. Berkaitan dengan hal itu, adanya program pengembangan lumbung hijauan pakan yang melibatkan kelompok-kelompok peternak sangat diperlukan pada wilayah tersebut. Pengembangan lumbung hijauan pakan ini juga memerlukan penguatan aspek penunjang dari segi teknologi dan kelembagaan. Ketersediaan hijauan pakan yang berlebih pada kelompok peternak tersebut dapat di ekspor ke kelompok lain atau pada wilayah lain yang kekurangan ketersediaan hijauan pakan, sehingga peternak dapat memperoleh nilai tambah dari pengolahan hijauan pakan tersebut.

Wilayah kelompok 2 merupakan wilayah non basis $(\mathrm{LQ}<1)$, dimana pada kelompok ini belum mampu untuk memenuhi kebutuhan ternak sapi potong pada wilayahnya sendiri karena jumlah populasi sapi potong cenderung sedikit. Peternak sebagai pelaku usaha (sumberdaya manusia) pada wilayah ini belum memiliki budaya (culture) yang kuat untuk pengembangan usaha sapi potong. Tingkat kapasitas pelayanan untuk usaha pengembangan sapi potong pada wilayah kelompok 2 masuk kategori tinggi (hierarki 1), yang artinya bahwa banyaknya jumlah sarana pelayanan dan jumlah jenis sarana pelayanan untuk pengembangan sapi potong pada wilayah tersebut sudah mampu memenuhi jumlah operasional yang optimal yang dibutuhkan dari hulu hingga hilir untuk melayani jumlah populasi sapi potong di wilayah tersebut. Berkaitan dengan hal itu, program produksi sapi potong yang dapat diarahkan untuk wilayah kelompok ini adalah program pembesaran anak sapi sapihan (growing stocker) dan penggemukan sapi (fattening). Wilayah kelompok ini kedepannya diharapkan dapat menjadi wilayah penyedia sarana pengamanan input untuk kebutuhan sapi bakalan yang akan digemukkan dan penggemukan sapi yang menghasilkan sapi siap potong, serta daging sapi yang berkualitas ASUH (Aman, Sehat, Utuh dan Halal).

Wilayah kelompok 3 (Kabupaten Banjarnegara, Jepara, Karangayar dan Magelang) mempunyai KPPTR positif (kelebihan ketersediaan hijauan pakan) sama seperti wilayah kelompok 1 dan 2. Berkaitan dengan hal itu, perlu adanya program pengembangan lumbung hijauan pakan yang melibatkan kelompok-kelompok peternak pada wilayah tersebut. Ketersediaan hijauan pakan yang berlebih pada kelompok peternak tersebut dapat di ekspor ke kelompok lain atau pada wilayah lain yang kekurangan ketersediaan hijauan pakan, sehingga peternak dapat memperoleh nilai tambah dari pengolahan hijauan pakan tersebut.

Wilayah kelompok 3 merupakan wilayah non basis $(\mathrm{LQ}<1)$, dimana pada kelompok ini belum mampu untuk memenuhi kebutuhan ternak sapi potong pada wilayahnya sendiri karena jumlah populasi sapi potong cenderung sedikit. Peternak sebagai pelaku usaha (sumberdaya manusia) pada wilayah ini belum memiliki budaya (culture) yang kuat untuk pengembangan usaha sapi potong. Tingkat kapasitas pelayanan untuk usaha pengembangan sapi potong pada wilayah kelompok 3 masuk kategori sedang (hierarki 2) dan rendah (hierarki 3), yang artinya bahwa 
banyaknya jumlah sarana pelayanan dan jumlah jenis sarana pelayanan untuk pengembangan sapi potong pada wilayah tersebut belum mampu memenuhi jumlah operasional yang optimal yang dibutuhkan dari hulu hingga hilir untuk melayani jumlah populasi sapi potong di wilayah tersebut.

Berkaitan dengan hal itu, program produksi sapi potong yang dapat diarahkan untuk wilayah kelompok 3 ini adalah program pembesaran anak sapi sapihan (growing stocker) dan penggemukan sapi (fattening) serta fasilitasi unit pelayanan untuk mendukung pengembangan sapi potong. Wilayah kelompok ini kedepannya diharapkan dapat menjadi wilayah penyedia sarana pengamanan input untuk kebutuhan sapi bakalan yang akan digemukkan dan penggemukan sapi yang menghasilkan sapi siap potong, serta daging sapi yang berkualitas ASUH (Aman, Sehat, Utuh dan Halal). Penguatan aspek penunjang dari segi teknologi dan kelembagaan sangat diperlukan untuk mendukung pengembangan sapi potong di wilayah ini.

Wilayah kelompok 4 (Kabupaten Klaten, Semarang, Temanggung dan Wonogiri) mempunyai KPPTR negatif (kekurangan ketersediaan hijauan pakan). Berkaitan dengan hal itu, perlu adanya kerjasama untuk ketersediaan hijauan pakan dengan melalukan impor dari wilayah lain yang terdekat yang memiliki KPPTR positif. Wilayah kelompok 4 merupakan wilayah non basis, dimana pada kelompok ini belum mampu untuk memenuhi kebutuhan ternak sapi potong pada wilayahnya sendiri karena jumlah populasi sapi potong cenderung sedikit. Peternak sebagai pelaku usaha (sumberdaya manusia) pada wilayah ini belum memiliki budaya (culture) yang kuat untuk pengembangan usaha sapi potong.

Tingkat kapasitas pelayanan untuk usaha pengembangan sapi potong pada wilayah kelompok 4 masuk kategori sedang (hierarki 2) dan rendah (hierarki 3), yang artinya bahwa banyaknya jumlah sarana pelayanan dan jumlah jenis sarana pelayanan untuk pengembangan sapi potong pada wilayah tersebut belum mampu memenuhi jumlah operasional yang optimal dari hulu hingga hilir untuk melayani jumlah populasi sapi potong di wilayah tersebut.

Jumlah sarana pada pusat-pusat pelayanan untuk kegiatan hulu pada kelompok 4 masih belum memenuhi jumlah yang dibutuhkan untuk operasionalnya, sehingga program produksi sapi potong pada wilayah kelompok ini dapat diarahkan pada kegiatan hilir yaitu program penggemukan sapi (fattening) dengan memanfaatkan pakan konsentrat dari limbah agroindustri. Pakan konsentrat ini selain dapat membantu mengurangi konsumsi hijauan pakan pada ternak, juga berfungsi untuk mengejar penambahan bobot badan harian pada ternak yang digemukkan.

Penguatan aspek penunjang dari segi teknologi dan kelembagaan untuk mendukung pengembangan sapi potong sangat diperlukan pada wilayah kelompok 4 ini. Fasilitasi unit pelayanan seperti pengembangan RPH yang bersertifikasi dan memenuhi standar operasional, sehingga untuk kedepannya wilayah kelompok ini dapat memenuhi kebutuhan daging sapi yang berkualitas ASUH (Aman, Sehat, Utuh dan Halal). Pengembangan industri yang bergerak dalam diversifikasi produk olahan daging sapi dan pengembangan industri kompos serta peningkatan mutu pengolahan limbah dan kotoran lainnya, sehingga mempunyai nilai tambah lebih dengan melibatkan peternak rakyat dan swasta.

Pengelompokkan wilayah-wilayah pengembangan sapi potong di Provinsi Jawa Tengah berdasarkan potensi masing-masing wilayah tersebut di atas, diharapkan dapat meningkatkan populasi, produksi dan produktivitas ternak serta nilai tambah bagi peternak sapi potong pada khususnya, dan sekaligus dapat meningkatkan peranan sapi potong dalam perekonomian di Provinsi Jawa Tengah pada umumnya. 
Tabel 6. Pengelompokkan Wilayah dan Strategi Pengembangan Sapi Potong di Provinsi Jawa Tengah

\begin{tabular}{|c|c|c|c|c|}
\hline Kabupaten & $\begin{array}{c}\text { KPPTR } \\
(\mathrm{ST})^{\mathrm{a}}\end{array}$ & $\mathbf{L Q}^{\mathbf{b}}$ & $\begin{array}{l}\text { Hierarki } \\
\text { Wilayahc }\end{array}$ & Strategi \\
\hline \multicolumn{5}{|c|}{ I. Wilayah Kelompok I } \\
\hline $\begin{array}{l}\text { Blora, Boyolali, } \\
\text { Kebumen, } \\
\text { Rembang, Pati, } \\
\text { Sragen }\end{array}$ & + & $>1$ & 3 & \multirow{2}{*}{$\begin{array}{l}\text { Pengembangan lumbung hijauan pakan,mensuplai } \\
\text { hijauan pakan wilayah KPPTR (-), dapat diarahkan } \\
\text { untuk wilayah pembibitan dan growing stocker, } \\
\text { fasilitasi unit pelayanan pengembangan sapi } \\
\text { potong, penguatan aspek penunjang (teknologi } \\
\text { dan kelembagaan) }\end{array}$} \\
\hline Grobogan & + & $>1$ & 2 & \\
\hline \multicolumn{5}{|c|}{ II. Wilayah Kelompok II } \\
\hline $\begin{array}{l}\text { Banyumas, } \\
\text { Brebes, Sukoharjo, } \\
\text { Tegal }\end{array}$ & + & $<1$ & 1 & $\begin{array}{l}\text { Pengembangan lumbung hijauan pakan, } \\
\text { mensuplai hijauan pakan wilayah KPPTR (-), dapat } \\
\text { diarahkan untuk wilayah growing stocker dan } \\
\text { penggemukan,penguatan aspek penunjang } \\
\text { (teknologi dan kelembagaan) }\end{array}$ \\
\hline \multicolumn{5}{|c|}{ III. Wilayah Kelompok III } \\
\hline $\begin{array}{l}\text { Banjarnegara, } \\
\text { Jepara, } \\
\text { Karanganyar, } \\
\text { Magelang }\end{array}$ & + & $<1$ & 3 & \multirow{2}{*}{$\begin{array}{l}\text { Pengembangan lumbung hijauan pakan, } \\
\text { mensuplai hijauan pakan wilayah KPPTR (-), d } \\
\text { diarahkan untuk wilayah growing stocker dan } \\
\text { penggemukan, fasilitasi unit pelayanan } \\
\text { pengembangan sapi potong, penguatan aspek } \\
\text { penunjang (teknologi dan kelembagaan) }\end{array}$} \\
\hline $\begin{array}{l}\text { Purbalingga, } \\
\text { Wonosobo }\end{array}$ & + & $<1$ & 2 & \\
\hline \multicolumn{5}{|c|}{ IV. Wilayah Kelompok IV } \\
\hline Klaten, Semarang & - & $<1$ & 3 & \multirow{2}{*}{$\begin{array}{l}\text { Kerjasama hijauan pakan dengan wilayah KPPTR } \\
(+) \text {, diarahkan untuk wilayah penggemukan } \\
\text { dengan memanfaatkan pakan konsentrat dari } \\
\text { limbah agroindustri, fasilitasi unit pelayanan } \\
\text { pengembangan sapi potong,penguatan aspek } \\
\text { penunjang (teknologi dan kelembagaan) }\end{array}$} \\
\hline $\begin{array}{l}\text { Temanggung, } \\
\text { Wonogiri }\end{array}$ & - & $<1$ & 2 & \\
\hline
\end{tabular}

\section{KESIMPULAN DAN SARAN}

\section{KESIMPULAN}

1. Peranan sapi potong di Provinsi Jawa Tengah memberikan kontribusi positif dalam pemenuhan kebutuhan daging sapi baik di tingkat provinsi maupun nasional, namun kontribusi sapi potong terhadap sumbangan PDRB dan penyerapan tenaga kerja di Provinsi Jawa Tengah masih relatif kecil.

2. Provinsi Jawa Tengah memiliki potensi ketersediaan hijauan pakan yang cukup besar, sehingga masih bisa menambah populasi ternak ruminansia (sapi potong).

3. Strategi untuk peningkatan peran sapi potong dalam perekonomian Provinsi Jawa Tengah adalah dengan pendekatan perencanaan wilayah, yang bertujuan untuk meningkatkan populasi dan produksi sapi potong, serta nilai tambah bagi peternak dan penyerapan tenaga kerja. Pengelompokkan wilayah pengembangan sapi potong menghasilkan 4 (empat) kelompok berdasarkan: wilayah sumber hijauan pakan, wilayah basis sapi potong dan hierarki wilayah berdasarkan tingkat kapasitas pelayanan untuk mendukung pengembangan sapi potong.

\section{SARAN}

1. Pemerintah daerah Provinsi Jawa Tengah dapat mengaplikasikan strategi pengembangan sapi potong berdasarkan perencanaan wilayah untuk peningkatan perekonomian.

2. Perlu mengoptimalkan kerjasama antar wilayah pengembangan sapi potong terkait dengan pemenuhan kontinuitas produksi yang berupa pengamanan input 
maupun dari segi pemasaran, penggunaan sarana penunjang serta peningkatan kapasitas sumber daya manusia melalui kegiatan-kegiatan pelatihan, magang dan studi banding antar wilayah.

3. Perlu ada penelitian lanjutan tentang unsur kelembagaan dan aspek penunjang lainnya yang berpengaruh dalam pengembangan sapi potong di Provinsi Jawa Tengah.

\section{DAFTAR PUSTAKA}

Arelovich HM, Bravo RD, Martínez MF. 2011. Development, Characteristics, and Trends for Beef Cattle Production in Argentina. Animal Frontiers. The Review Magazine of Animal Agriculture. doi: 10,2527/ af.2011-0021 Animal Frontiers 2011 vol.1no.2 37-45.

Arfa'I dan Erison. 2010. Pengembangan Ternak Sapi Potong Melalui Pendekatan Lahan dan Sumber Daya Peternak di Kabupaten Pariaman Sumatera Barat [Working Paper]. Padang (ID): Lembaga Penelitian Universitas Andalas.

[BKP] Badan Ketahanan Pangan. 2013. Direktori Pengembangan Konsumsi Pangan. Jakarta (ID): Badan Ketahanan Pangan Kementerian Pertanian.

[BPS Jateng] Badan Pusat Statistik Provinsi Jawa Tengah. 2013. Jawa Tengah dalam Angka 2013 (Central Java in Figures 2013). Semarang (ID): Badan Pusat Statistik Provinsi Jawa Tengah.

Daryanto A. 2009. Dinamika Daya Saing Industri Peternakan. Bogor (ID): IPB Press.

[Dinas PKH Provinsi Jateng] Dinas Peternakan dan Kesehatan Hewan Provinsi Jawa Tengah. 2014. Statistik Peternakan Tahun 2014. Semarang (ID): Dinas Peternakan dan Kesehatan Hewan Provinsi Jawa Tengah.
[Ditjen PKH] Direktorat Jenderal Peternakan dan Kesehatan Hewan. 2011. Rencana Strategis Direktorat Jenderal Peternakan dan Kesehatan Hewan 2010-2014 Edisi Revisi. Jakarta [ID]: Direktorat Jenderal Peternakan dan Kesehatan Hewan Kementerian Pertanian.

[Ditjen PKH] Direktorat Jenderal Peternakan dan Kesehatan Hewan. 2012. Pedoman Pelaksanaan Pengembangan Kawasan Sapi dan Kerbau. Jakarta (ID): Direktorat Jenderal Peternakan dan Kesehatan Hewan Kementerian Pertanian.

[Ditjen PKH] Direktorat Jenderal Peternakan dan Kesehatan Hewan. 2013. Statistik Peternakan dan Kesehatan Hewan. Jakarta (ID): Direktorat Jenderal Peternakan dan Kesehatan Hewan Kementerian Pertanian.

[Ditjen PKH] Direktorat Jenderal Peternakan dan Kesehatan Hewan.2014. Bahan Rapat Pimpinan: Supply dan Demand Daging Sapi Tahun 2010-2014. Jakarta (ID): Direktorat Jenderal Peternakan dan Kesehatan Hewan Kementerian Pertanian.

Huyen LTT, Tuyet DTV, Markemann A, Herold P dan Zárate AV. 2012. Beef Cattle Keeping By Smallholders in A Mountainous Province of Northern Vietnam In Relation To Poverty Status, Community Remoteness And Ethnicity. Journal Animal Production Science53 (2) 163-172.doi.org/10.1071/AN12117.

Lamsihar NLT. 2013. Sumber Bahan Pakan dan Pakan Ternak Ruminansia. Jakarta (ID): Direktorat Pakan Ternak Direktorat Jenderal Peternakan dan Kesehatan Hewan.

Mayulu H, Sunarso, Sutrisno CI, Sumarsono. 2010. Kebijakan Pengembangan PeternakanSapi Potong di Indonesia.Jurnal Litbang Pertanian. 29 (1):34-41. 
[MB-IPB] Program Pascasarjana Manajemen dan Bisnis Institut Pertanian Bogor. 2012. Laporan Akhir: Kajian Supply Chain Ternak Sapi dan Daging di Indonesia 2012. Kerjasama Direktorat Jenderal Peternakan dan Kesehatan Hewan Kementerian Republik Indonesia dengan Program Pascasarjana Manajemen dan Bisnis Institut Pertanian Bogor. Bogor (ID): Program Pascasarjana Manajemen dan Bisnis Institut Pertanian Bogor.

Priyanto D. 2011. Strategi Pengembangan Usaha Ternak Sapi Potong dalam Mendukung Program Swasembada Daging Sapi dan Kerbau Tahun 2014. Jurnal Litbang Pertanian 30 (3):108-116.

[P4UI] Pusat Penelitian Pranata Pembangunan Universitas Indonesia. 2013. Kajian Indeks Distribusi Ternak dan Daging Sapi. Kerjasama Direktorat Jenderal Peternakan dan Kesehatan Hewan Kementerian Republik Indonesia dengan Pusat Penelitian Pranata Pembangunan Universitas Indonesia. Jakarta. Jakarta (ID): Pusat Penelitian Pranata Pembangunan Universitas Indonesia.

Rustiadi E, Saefulhakim S, Panuju DR. 2011. Perencanaan dan Pengembangan Wilayah. Jakarta (ID): Crestpent Press dan Yayasan Pustaka Obor Indonesia.

Rustiadi E dan Panuju DR. 2012. Teknis Analisis Perencanaan Pengembangan Wilayah. Bogor (ID): Bagian Perencanaan Pengembangan Wilayah Departemen Ilmu Tanah dan Sumber Daya Lahan Institut Pertanian Bogor.

Safitri T. 2011. Penerapan Good Breeding Practices Sapi Potong di PT. Lembu Jantan Perkasa Serang-Banten. [Skripsi]. Bogor (ID): Institut Pertanian Bogor.

Salim E. 2013. Sukses Bisnis dan Beternak Sapi Potong. Yogyakarta (ID): Andi Publisher.
Tabrany H. 2006. Kajian Potensi Pakan dari Limbah Pertanian dan Limbah Industri Pertanian sebagai Pakan Ternak Ruminansia di Wilayah Jawa Tengah. [Disertasi]. Bogor (ID): Institut Pertanian Bogor. 
